\title{
Ancient and Modern Geochemical Signatures in the 13,500-Year Sedimentary Record of Lake Cadagno
}

\section{OPEN ACCESS \\ Edited by:}

Alexandra V. Turchyn,

University of Cambridge,

United Kingdom

Reviewed by:

Tobias Goldhammer,

Leibniz-Institute of Freshwater

Ecology and Inland Fisheries (IGB),

Germany

Dirk de Beer,

Max Planck Society, Germany

${ }^{*}$ Correspondence:

Jasmine S. Berg

jasmine.berg@unil.ch

${ }^{\dagger}$ Present address:

Jasmine S. Berg,

Institute of Earth Surface Dynamics

(IDYST), University of Lausanne,

Lausanne, Switzerland

Xingguo Han,

Federal Institute for Forest, Snow, and

Landscape Research (WSL),

Birmensdorf, Switzerland

Marina A. Morlock,

Department of Ecology and

Environmental Sciences, Umeå

Universitet, Umeå, Sweden

Specialty section:

This article was submitted to Biogeoscience,

a section of the journal

Frontiers in Earth Science

Received: 07 August 2021 Accepted: 20 December 2021

Published: 31 January 2022

Citation:

Berg JS, Lepine M, Laymand E, Han X, Vogel H, Morlock MA, Gajendra N, Gilli A, Bernasconi SM, Schubert CJ, Su G and Lever MA (2022) Ancient and Modern Geochemical Signatures in the 13,500-Year Sedimentary Record of

Lake Cadagno.

Front. Earth Sci. 9:754888 doi: $10.3389 /$ feart.2021.754888
Jasmine S. Berg ${ }^{1 \dagger *}$, Mathilde Lepine ${ }^{1}$, Emile Laymand ${ }^{1}$, Xingguo Han ${ }^{1 \dagger}$, Hendrik Vogel ${ }^{2}$, Marina A. Morlock ${ }^{2+}$, Niroshan Gajendra ${ }^{1}$, Adrian Gilli ${ }^{3}$, Stefano M. Bernasconi ${ }^{3}$, Carsten J. Schubert ${ }^{1,4}$, Guangyi Su ${ }^{4}$ and Mark A. Lever ${ }^{1}$

${ }^{1}$ Department of Environmental Systems Science, ETH-Zurich, Zurich, Switzerland, ${ }^{2}$ Institute of Geological Sciences, University of Bern, Bern, Switzerland, ${ }^{3}$ Department of Earth Sciences, ETH-Zurich, Zurich, Switzerland, ${ }^{4}$ Surface Waters-Research and Management, Swiss Federal Institute of Aquatic Science and Technology (EAWAG), Dübendorf, Switzerland

Although lake sediments are globally important organic carbon sinks and therefore important habitats for deep microbial life, the deep lacustrine biosphere has thus far been little studied compared to its marine counterpart. To investigate the impact of the underexplored deep lacustrine biosphere on the sediment geochemical environment and vice versa, we performed a comprehensive microbiological and geochemical characterization of a sedimentary sequence from Lake Cadagno covering its entire environmental history since formation following glacial retreat. We found that both geochemical gradients and microbial community shifts across the $\sim 13.5 \mathrm{kyr}$ subsurface sedimentary record reflect redox changes in the lake, going from oxic to anoxic and sulfidic. Most microbial activity occurs within the top $20 \mathrm{~cm}$ of sediment, where millimolar sulfate concentrations diffusing in from the bottom water are almost completely consumed. In deeper sediment layers, organic carbon remineralization is much slower but microorganisms nonetheless subsist on fermentation, sulfur cycling, metal reduction, and methanogenesis. The most surprising finding was the presence of a deep, oxidizing groundwater source. This water source generates an inverse redox gradient at the bottom of the sedimentary sequence and could contribute to the remineralization of organic matter sequestered in the energy-limited deep subsurface.

Keywords: lake sediments, deep biosphere, bacteria, archaea, redox gradients

\section{INTRODUCTION}

Globally lake sediments accumulate organic carbon at an estimated annual rate of about $42 \mathrm{Tg} \mathrm{yr}^{-1}$ (Dean and Gorham, 1998), representing a significant sink for organic matter and a huge potential reservoir for microbial life. Continued sedimentation over geologic time buries deposited organic matter, including microbial cells, along with inorganic minerals and pore water deeper and deeper, thus preserving geochemical signatures from the time of deposition. Furthermore, due to the great sensitivity of lakes to environmental changes on the surrounding land (e.g., glacial retreat, permafrost thawing, soil development), lake sediments can serve as natural archives of regional climatological and ecological variations over time.

The influence of microorganisms on the sedimentary carbon reservoir is greatest in surface sediments, where much of the deposited organic matter is microbially accessible and easily degradable, and high energy microbial electron acceptors, such as $\mathrm{O}_{2}$ and nitrate are present 
(Carlton et al., 1989). Yet, even in deeper layers, in which these electron acceptors are depleted, and the residual organic matter is increasingly recalcitrant to degradation, microbial activity can have a significant impact on the storage of organic carbon over time scales of thousands to millions of years. In these deeper, anoxic sediments, the microbial breakdown of organic carbon is carried out by a network of microorganisms. Primary fermenters perform the initial extracellular hydrolysis of organic macromolecules and gain energy by converting the released mono- and oligomers to smaller compounds, such as $\mathrm{H}_{2}$, short-chain organic acids, or alcohols [e.g., (Schink, 1997)]. The resulting smaller compounds are then respired to $\mathrm{CO}_{2}$ or $\mathrm{CH}_{4}$ by microorganisms, which use nitrate, metal oxides, sulfate, or $\mathrm{CO}_{2}$ as electron acceptors. Alternatively, short-chain organic acids and alcohols produced by primary fermenters may first be converted to $\mathrm{H}_{2}$ or $\mathrm{C} 1$ compounds by secondary fermenters before being respired to $\mathrm{CO}_{2}$ and/or $\mathrm{CH}_{4}$.

In anoxic lake sediments with high sedimentation rates, $\mathrm{CO}_{2}$ reduction to methane (methanogenesis) and iron [Fe(III)] reduction are the dominant microbial respiration reactions (Lovley and Phillips, 1986; Capone and Kiene, 1988; Roden and Wetzel, 1996). Despite generally low sulfate concentrations in freshwater environments, efficient recycling of this terminal electron acceptor may increase the importance of sulfur respiration pathways (Bak and Pfennig, 1991; Urban et al., 1994; Hansel et al., 2015). While evidence shows that these biogeochemical processes continue to be important in deep submarine sediments (Onstott et al., 1999), little data is available from deep lake sediments. Differences in trophic state, water chemistry, and the quality and quantity of organic matter input between lakes and oceans make it difficult to generalize across such contrasting environments. Moreover, it is known from marine sediments that metabolic activities may deviate from the standard energetic model and that deep geologic interfaces, e.g., of sediments with underlying aquifers, can supply dissolved electron acceptors, such as $\mathrm{O}_{2}$, nitrate, or sulfate to deep sediment layers (D'Hondt et al., 2004; Parkes et al., 2005; Jørgensen et al., 2020).

The microorganisms driving biogeochemical processes in deep lake sediments have been much less studied than their marine counterparts. Since microbial activity and cell concentrations in subseafloor sediments correlate with the sedimentation rate of organic matter (Kallmeyer et al., 2012), the lacustrine subsurface biosphere can also be expected to vary greatly across different lake environments. At this time, deep sediment microbial communities of very few lakes have been investigated (Glombitza et al., 2013; Thomas et al., 2014; Thomas et al., 2020; Vuillemin et al., 2016; Vuillemin et al., 2018) and far more studies will be needed to understand lake subsurface ecosystems. These sediment records spanning up to 50,000 years of depositional history demonstrate that the structure and composition of microbial communities is strongly linked to lake sediment lithology, which derives from the water column conditions and prevailing climate at the time of deposition. Despite differences in initial seed communities, microbial diversity in these lacustrine subsurface environments has thus far proven surprisingly similar to that in deep marine sediment, though clades unique to lacustrine environments do exist (Ariztegui et al., 2015). Nonetheless, large contrasts in microbial cell densities and activities exist even across a single lake basin and appear to be correlated with sediment organic matter quantity and quality (Vuillemin et al., 2016).

Due to the sequential changes in its redox and sediment depositional history, Lake Cadagno in the Piora Valley of the Swiss Alps provides a suitable limnological record for studying biogeochemical processes as a function of sediment age and lithology. Situated at 1,921 m altitude, this lake formed during glacial retreat and has since undergone transformations from oxic, to suboxic, to completely anoxic bottom waters (Wirth et al., 2013). Today the permanently stratified lake is often cited as an Archaean ocean analogue for its sulfate-rich $(\sim 2 \mathrm{mM})$, anoxic bottom water, which harbors biogeochemical processes that may have been widespread on early Earth (Canfield, 1998; Poulton et al., 2004). In order to understand how variations in sediment types and sources (terrestrial vs. lacustrine), variations in organic carbon quality (based on $\delta^{13} \mathrm{C}$-TOC and $\mathrm{C}: \mathrm{N}$ ), and past changes in water column chemistry and resulting sediment redox conditions shape subsurface lacustrine microbial communities, we performed a comprehensive biogeochemical analysis of the complete sedimentary record of Lake Cadagno. By combining pore water and solid-phase geochemical analyses with quantitative and high-throughput sequencing of 16S rRNA genes, we reveal an unexpected distribution of biogeochemical processes and microbial communities influenced by a subsurface aquifer. These results provide new insights into the strong link between lacustrine sediment geochemistry and resident microbial populations, whose contribution to diagenetic processes there are generally overlooked in Quaternary studies.

\section{METHODS}

\section{Study Site and Field Sampling}

Lake Cadagno is a crenogenic meromictic lake located in the Swiss Alps at 1,921 $\mathrm{m}$ above sea level (46.55060 N and 8.71201 E). Subaquatic springs flowing through dolomitic bedrock supply the lake with high concentrations of $\mathrm{Mg}^{2+}, \mathrm{Ca}^{2+}, \mathrm{HCO}_{3}{ }^{-}$, and $\mathrm{SO}_{4}{ }^{2-}$, the latter of which is respired by sulfate-reducing microorganisms generating a sulfidic hypolimnion and underlying sediments. A previous study of a $\sim 10$-m sedimentary succession reaching from the sediment-water interface to the underlying late glacial sediments revealed that the $21 \mathrm{~m}$-deep lake basin formed after glacial retreat about 12,500 thousand years ago and underwent a several-hundred-year redox transition interval before shifting to fully anoxic, sulfidic conditions (Wirth et al., 2013). Correspondingly, the sedimentary record hosts three main lithological units: late glacial deposits poor in organic matter, a Mn-enriched redox transition zone, and metal sulfide-rich sediments. Lipid biomarkers of anoxygenic phototrophic bacteria have been recovered from the metal sulfide-rich layers and indicate anoxic, hydrogen sulfide-rich conditions in overlying lake water throughout the time of deposition (Wirth et al., 2013). These euxinic sediments are additionally characterized by discrete sediment layers of different origins: 
laminated to thinly bedded pelagic lacustrine muds, graded coarse-grained terrestrial flood deposits, and mass-movement (i.e., gravity-driven mudslide) deposits containing remobilized lacustrine and/or terrestrial sediment. To investigate how the depositional history, lithology, and redox history of these sediments have shaped biogeochemical processes and associated microbial communities through time, a second piston-coring campaign was undertaken in Lake Cadagno in August 2019.

Three sets of piston cores (Supplementary Figure S1) were recovered using a Uwitec coring platform (Uwitec, AT) of the ETH Zurich's Limnogeology Group. This coring platform recovers 3-m long and $6-\mathrm{cm}$ diameter core sections using a percussion piston-coring system. The three piston cores were obtained from parallel boreholes in the deepest part of the lake (46.55060 $\mathrm{N}$ and $8.71201 \mathrm{E}$, no more than \pm 0.00003 decimal degrees or $\sim 3 \mathrm{~m}$ apart). Florist foam soaked with lake surface water was used to fill any remaining empty space in the top of the core liner before sealing with rubber caps at each end. Each core section was carried to the Alpine Biology Center field laboratory on shore for immediate sample processing. For high-resolution analyses of undisturbed surface sediments, additional short cores were retrieved from the same location using a UWITEC gravity corer using clear plastic liners with $1 \mathrm{~m}$ length and $9 \mathrm{~cm}$ inner diameter.

The first set of long cores was reserved for non-destructive imaging analyses. The second set of long cores was dedicated to pore water extraction using syringes connected to Rhizons $(0.2 \mu \mathrm{m}$ pore size, Rhizosphere) inserted into holes drilled horizontally every $10 \mathrm{~cm}$ into the core liners after collection. Rhizons, stopcocks and syringes were first flushed with $2-3 \mathrm{ml}$ of pore water to remove contaminant air. Porewater was then distributed into separate vials with appropriate fixatives for downstream analyses. Samples from the top $30 \mathrm{~cm}$ of each core were discarded due to the likely infiltration of surface water in the florist foam. The third set of long cores was dedicated to analyses of DNA, dissolved gases, solid-phase C, $\mathrm{Fe}$, and $\mathrm{S}$ pools, and physical properties. Sampling windows were cut into the core liners every $20 \mathrm{~cm}$ using a hand-held vibrating saw and potentially contaminated sediment in contact with the liner was scraped away. Samples were then taken using sterile, cut-off syringes. After sampling, all cores were sliced into 1-m sections and split longitudinally for high-resolution photography to enable alignment of parallel cores and to establish a continuous composite core record.

\section{Age Model Construction and X-Ray Fluorescence Core Scanning}

The chronology of the 2019 core composite is based on 9 radiocarbon dates which were transferred from the previously studied 2009 Lake Cadagno core succession (Wirth et al., 2013). Transfer of dates is based on aligning the characteristic lithologies from which the dates were obtained between the two composite sediment core successions. Upon age-depth modeling using linear interpolation and the clam $\mathrm{R}$ software package (Version 2.4.0; Blaauw, 2010), ${ }^{14} \mathrm{C}$ ages were converted into calibrated ${ }^{14} \mathrm{C}$ ages (cal kyr BP) using the IntCal13 calibration curve (Reimer et al., 2013). We removed event deposits (flood layers, slumps) $>2 \mathrm{~mm}$ prior to age-depth modelling and reinserted these into the chronostratigraphy following age-depth modeling using a constant age for each individual deposit.

The radiocarbon ages of the lacustrine sediment succession from $780 \mathrm{~cm}$ to the sedimentwater interface documents continuous sedimentation during the past $\sim 12.5$ kyrs (Figure 1). Based on this age-model we estimate the duration of the transition period with Mn-oxide layer deposition to have lasted between $~ 12.5$ (780 $\mathrm{cm})$ to $\sim 10.9(760 \mathrm{~cm})$ kyrs BP. Euxinic conditions persisted continuously since $10.9(760 \mathrm{~cm})$ kyrs BP.

\section{Porewater Chemistry}

Samples for analysis of dissolved metals (Fe, Mn) were acidified with $5 \mu \mathrm{L}$ of $30 \% \mathrm{HCl}$ per $2 \mathrm{ml}$ to prevent precipitation and measured by inductively coupled plasma optical emission spectroscopy (ICP-OES, Agilent Technologies 5100). Porewater for dissolved inorganic carbon (DIC) analysis was filled into $1.5 \mathrm{ml}$ borosilicate vials and capped without headspace to avoid degassing of $\mathrm{CO}_{2}$ and then stored at $4^{\circ} \mathrm{C}$ for up to 8 weeks. To measure $\delta^{13} \mathrm{C}$-DIC, samples were transferred to He-flushed Exetainers immediately containing $200 \mu \mathrm{L}$ of $85 \%$ phosphoric acid to convert all DIC to $\mathrm{CO}_{2}$. The $\mathrm{CO}_{2}$ in the headspace was analyzed on a GasBench II (ThermoFisher Scientific) coupled with an isotope ratio mass spectrometer (Delta V, ThermoFisher Scientific). Carbon isotopes are reported in the conventional delta notation with respect to the Vienna Pee Dee Belemnite (V-PDB) standard. For dissolved sulfide analyses, pore water was fixed with $\mathrm{Zn}$-acetate solution to $0.5 \%$ final concentration and quantified photometrically using the methylene blue method (Cline, 1969). Samples for dissolved ion $\left(\mathrm{PO}_{4}{ }^{3-}, \mathrm{NO}_{2}{ }^{-}, \mathrm{NO}_{3}{ }^{-}, \mathrm{SO}_{4}{ }^{2-}\right.$, $\mathrm{NH}_{4}{ }^{+}$) analyses were immediately frozen at $-20^{\circ} \mathrm{C}$ until analysis on an ion chromatograph (DX-ICS-1000, DIONEX) equipped with an AS11-HC column. Carbonate buffer $\left(3.2 \mathrm{mmol} \mathrm{L}^{-1}\right.$ $\mathrm{Na}_{2} \mathrm{CO}_{3}$ and $1 \mathrm{mmol} \mathrm{L}^{-1} \mathrm{NaHCO}_{3}$ ) was used as eluent at a flow rate of $1 \mathrm{ml} \mathrm{min}^{-1}$ with a total run duration of $14 \mathrm{~min}$. Nitrite, nitrate, phosphate, and sulfate eluted at 5.8, 8.0, 9.7, and $11.9 \mathrm{~min}$, respectively. Ammonium was determined photometrically using the indophenol blue method (Kempers and Kok, 1989).

\section{Dissolved Methane}

For dissolved methane quantification, $3 \mathrm{~cm}^{3}$ of sediment was immediately transferred to $20 \mathrm{ml}$ glass vials containing $7 \mathrm{ml}$ of $10 \% \mathrm{NaOH}$, sealed with a butyl rubber stopper, and homogenized by shaking (Blees et al., 2014). Methane concentrations in the headspace were measured using a gas chromatograph (GC, Agilent $6890 \mathrm{~N}$ ) with a flame ionization detector and $\mathrm{He}$ as a carrier gas.

\section{Solid Phase Carbon, Nitrogen, Iron, and Sulfur Analyses}

Using a cut-off plastic syringe, $5 \mathrm{~cm}^{3}$ of sediment were obtained from each depth interval, transferred to clean glass vials with 
screw caps, and stored at $-20^{\circ} \mathrm{C}$ until further processing. Porosity was determined from weight loss after heating the sediment at $70^{\circ} \mathrm{C}$ until complete dryness. Total carbon (TC) and total nitrogen (TN) were determined from this dried sediment by EA-IRMS as described below. Total organic carbon (TOC) was determined after acid-extraction of inorganic carbon with concentrated $6 \mathrm{~N}$ $\mathrm{HCl}$. Total inorganic carbon (TIC) was calculated as the difference between TC and TOC.

An additional $\sim 10 \mathrm{~cm}^{3}$ (or more) of fresh sediment from each depth were transferred to sterile, gas-tight plastic bags (WhirlPak) and sealed after pressing out all the air before freezing at $-20^{\circ} \mathrm{C}$. For solid phase iron and sulfur extractions, bagged sediments were thawed in a cold-water bath and then, avoiding the sediment in contact with the plastic bag, a subsample was quickly transferred to a degassed glass vial and freezedried overnight. Less than $100 \mathrm{mg}$ of the dried sediment was weighed into a $15 \mathrm{ml}$ Falcon tube containing $0.25 \mathrm{mM} \mathrm{HCl}$ for reactive iron analysis, and the remainder of sediment was stored anoxically for sulfur extractions. Reactive iron was extracted for $1 \mathrm{~h}$ on a shaker prior to centrifugation and photometric determination of $\mathrm{Fe}(\mathrm{II}) / \mathrm{Fe}$ (III) in the supernatant using the ferrozine assay (Stookey, 1970).

Elemental sulfur was extracted three times under an $\mathrm{N}_{2}$ atmosphere with degassed $100 \%$ methanol. During each step the methanol-sample mixture was sonicated for $10 \mathrm{~min}$ in an ice bath, centrifuged, and then the methanol was pipetted into a clean vial. Methanol extracts were analyzed by ultrahigh pressure liquid chromatography (UPLC) using a Waters Acquity H-class instrument with an Aquity UPLC BEH C18, $1.7 \mu \mathrm{m}, 2.1 \mathrm{~mm} \times$ $50 \mathrm{~mm}$ column (Waters, Japan) and a PDA detector (absorbance wavelength set to $265 \mathrm{~nm}$ ). The injection volume was $10 \mu \mathrm{L}$ with methanol as eluent flowing at $0.2 \mathrm{ml} \mathrm{min}^{-1}$. Elemental sulfur eluted at $4.14 \mathrm{~min}$.

\section{Concentration and Stable Isotopic Analyses of Carbon and Nitrogen Pools}

The concentrations and isotopic compositions of nitrogen and carbon in different sediment fractions were determined simultaneously using a Flash-EA 1112 (ThermoFisher Scientific) coupled to an isotope ratio mass spectrometer (IRMS, Delta V, ThermoFisher Scientific). Isotope ratios are reported in the conventional $\delta$-notation with respect to atmospheric $\mathrm{N}_{2}$ (AIR) and Vienna Pee Dee Belemnite (V-PDB) standards, for nitrogen and carbon, respectively. The system was calibrated with IAEA-N1 $\left(\delta^{15} \mathrm{~N}=+0.45\right)$, IAEA-N2 $\left(\delta^{15} \mathrm{~N}=+20.41\right)$ and IAEA N3 $\left(\delta^{15} \mathrm{~N}=+4.72\right)$ reference materials for nitrogen, and NBS22 $\left(\delta^{13} \mathrm{C}=-30.03\right)$ and IAEA CH- $6\left(\delta^{13} \mathrm{C}=\right.$ $-10.46)$ for carbon. The reproducibility of measurements was better than $0.2 \%$ or both elements.

\section{Diffusive Flux Calculations}

Fluxes of $\mathrm{SO}_{4}{ }^{2-}$ in the upper and lower sulfate-depletion zones were calculated from linear pore water concentration gradients at $4-20 \mathrm{~cm}$ and $800-830 \mathrm{~cm}$. Methane fluxes were calculated for gradients at $4-20 \mathrm{~cm}$ and $750-800 \mathrm{~cm}$ depth. Fick's first law was used as follows:

$$
J=-\varphi D_{\text {sed }} \frac{\partial C_{i}}{\partial z}
$$

where $J$ is the diffusive flux (in mmol m $\mathrm{m}^{-2} \mathrm{~d}^{-1}$ ), $\varphi$ is the mean local sediment porosity (see Supplementary Table S1), $C$ is the concentration of molecule $i$ (in mmol per $\mathrm{m}^{3}$ of pore water), and $z$ is the sediment depth (in mblf). $D_{\text {sed }}$ is the sediment diffusion coefficient (in $\mathrm{cm}^{2} \mathrm{~s}^{-1}$ ) for in situ conditions and corrected for tortuosity (Boudreau, 1997):

$$
D_{\text {sed }}=D_{0} /\left(1-\ln \left(\varphi^{2}\right)\right)
$$

Molecular diffusion coefficients $\left(D_{0}\right)$ selected assuming an in situ temperature of $8^{\circ} \mathrm{C}$ in the Lake Cadagno sediments were $6.74 \times$ $10^{-10} \mathrm{~m}^{2} \mathrm{~s}^{-1}$ and $1.11 \times 10^{-9} \mathrm{~m}^{2} \mathrm{~s}^{-1}$ for $\mathrm{SO}_{4}{ }^{2-}$ and $\mathrm{CH}_{4}$, respectively.

\section{DNA Extraction and Sequencing}

For DNA analyses, $\sim 4 \mathrm{~cm}^{3}$ of sediment from each depth were transferred to sterile $5-\mathrm{cm}^{3}$ cryovials, immediately flash-frozen in liquid $\mathrm{N}_{2}$, and stored at $-80^{\circ} \mathrm{C}$ until further processing. DNA was extracted according to (Lever et al., 2015) using Lysis Protocol II followed by $2 \times$ washing with chloroform-isoamylalcohol (24:1), precipitation with ethanol-sodium chloride-linear polyacrylamide, and post-extraction clean up with the Norgen CleanAll DNA/RNA Clean-Up and Concentration Micro Kit [further details in (Lever et al., 2015)]. Prior to lysis, $0.2 \mathrm{~g}$ sediment aliquots were soaked in $100 \mu \mathrm{L}$ hexametaphosphate solution to minimize DNA adsorption to sediment grains. The concentration of hexametaphosphate was $10 \mathrm{mM}$ in all samples except those from organic-poor glacial clay ( $\geq 782 \mathrm{cmblf}$ ), where they were increased to $100 \mathrm{mM}$ due to the otherwise very high adsorptive losses.

$16 \mathrm{~S}$ rRNA gene concentrations in purified genomic DNA extracts were quantified using SYBR Green I Master on a LightCycler 480 II (Roche Molecular Systems, Inc.). The primer pairs for Bacteria and Archaea were Bac908F_mod (5'-AAC TCA AAK GAA TTG ACG GG-3') (Lever et al., 2015)/Bac1075R (5' CAC GAG CTG ACG ACA RCC-3') (Ohkuma and Kudo, 1998) and Arch915F_mod ( $5^{\prime}$-AAT TGG CGG GGG AGC AC-3') (Cadillo-Quiroz et al., 2006)/Arch1059R (5'-GCC ATG CAC CWC CTC T-3') (Yu et al., 2005), respectively. The thermal cycler protocols followed those outlined in Lever et al. (2015).

For amplicon sequencing, the V3-V4 hypervariable regions of bacterial and archaeal 16S rRNA genes was amplified using the primer pairs S-D-Bact-0341-b-S-17 (5'-CCT ACG GGN GGC WGC AG-3')/S-D-Bact-0785-a-A-21 (5'-GAC TAC HVG GGT ATC TAA TCC-3') (Herlemann et al., 2011) for Bacteria and S-D-Arch-0519-a-A-19 (5'-CAG CMG CCG CGG TAA HAC C$3^{\prime}$ ) (Sørensen and Teske, 2006)/967Rmod (5'-GTG CTC CCC CGC CAA TT-3') (Cadillo-Quiroz et al., 2006) for Archaea. Additionally, to investigate potential primer biases, 16S rRNA genes from a subset of samples spanning the entire sediment column were amplified using the universal prokaryotic primers Univ519F (5'-CAG CMG CCG CGG TAA-3')/Univ802R ( $5^{\prime}$ TAC NVG GGT ATC TAA TCC-3') (Claesson et al., 2009; Wang and Qian, 2009). Amplicon libraries were prepared in-house starting with a booster PCR (threshold number of qPCR cycle plus three additional cycles) to obtain similar amplicon 




FIGURE 1 | (Left) Lithological profile determined from a composite core image of the sedimentary sequence retrieved from Lake Cadagno. The age model was calibrated with previously obtained radiocarbon dates from corresponding sedimentary layers (Wirth et al., 2013). (Right) XRF profiles of Fe/Ti and Mn/Ti. Inset shows the Mn enrichment in the redox transition interval.

concentrations across all samples, followed by a tailed-primer PCR (10 cycles) and an index PCR (8 cycles). Further details can be found in (Deng et al., 2020) for the universal bacterial and archaeal primer pairs, and in Han et al. (2020) for the universal primer pair). Paired-end sequencing was performed on a MiSeq Personal Sequencer (Illumina Inc., San Diego, California, United States).

\section{Sequencing Data Processing and Analysis}

Phylogenetic analyses of DNA sequences were performed as described previously (Deng et al., 2020). For low biomass samples, potential contaminants were manually removed based on lists of common laboratory contaminants (Sheik et al., 2018; Karstens et al., 2019) and sequences present in negative controls (Supplementary Figure S2). After decontamination 2,053,665 bacterial and 4,506,390 archaeal reads remained (details provided in Supplementary Material). Sequences were denoised and assembled into Zero-radius Operational Taxonomic Units (ZOTUs) and then grouped at a 97\% identity threshold for all further analyses. In other words, ZOTU is a cluster of DNA sequences that are highly similar and can be considered a rough proxy for a species. Bacterial 16S rRNA gene sequences were phylogenetically annotated based on the SILVA small subunit referenced database (release no. 128). Archaeal 16S rRNA gene sequences were phylogenetically assigned in ARB (www.arbhome.de) using neighbour-joining phylogenetic trees that were based on a manually optimized SILVA database that included upto-date 16S rRNA gene sequences from whole-genome studies. Statistical analyses were performed in R v3.4.0 (http://R-project. org) using R Studio v1.1.442 (http://rstudio.com). Raw sequences have been deposited in Sequence Read Archive with accession numbers SAMN20601530-SAMN20601580 under the project PRJNA752598.

\section{RESULTS}

\section{Lithological Description and Age Model for Lake Cadagno Sediment Cores}

The 9.6-m Sediment succession recovered from Lake Cadagno spans the entire sedimentary history of the lake down to 

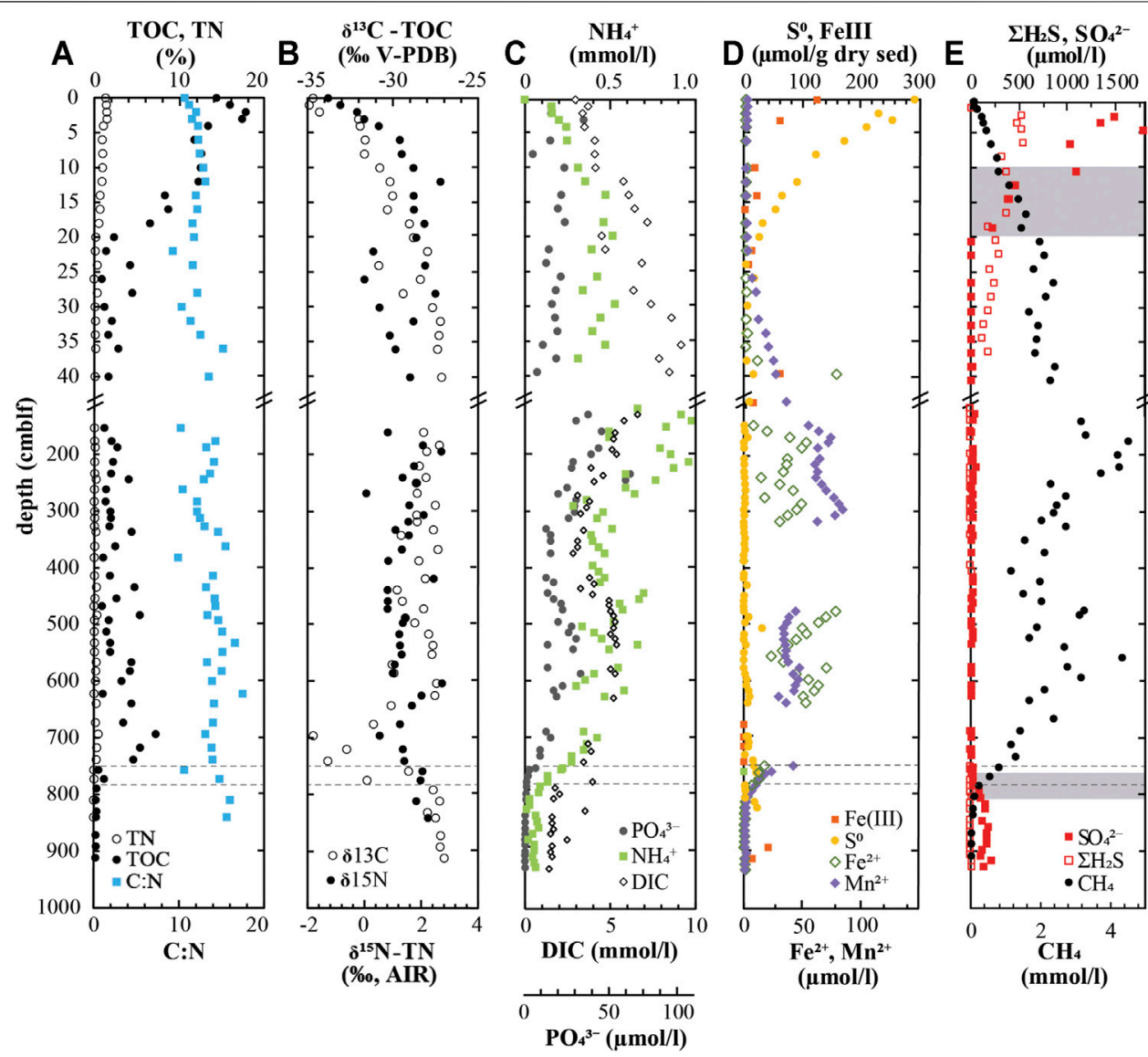

FIGURE 2 | (A-E) Geochemical profiles from the sediments of Lake Cadagno. Note the break in the y-axis showing the upper 40-cm of sediment in high-resolution. Dashed lines indicate the geological transition intervals and shaded regions in (E) denote the sulfate depletion zones. Large gaps in (D) are due to insufficient sample volume to measure all compounds.

sediments that were deposited following glacial retreat from the depression (Figure 1). The lithostratigraphy is characterized by alternating laminated to thinly bedded pelagic lacustrine sediment and turbidites of varying thickness $(<2-30 \mathrm{~mm})$, originating from flood and mass-movement events in the upper $780 \mathrm{~cm}$. Turbidite deposits are mainly composed of sand-sized grains of terrestrial source with a minor contribution from remobilized lacustrine sediment. Below $780 \mathrm{~cm}$, the sediment is composed of light gray, predominantly detrital clastic late glacial deposits with individual sediment beds marked by variations in grain-size ranging from silt to sand (Supplementary Figure S1). During the oxic period following glacial retreat, $\mathrm{Mn}$ and Fe likely entered the lake as detrital input and were oxidized, precipitated, reduced in sediments and diffused back into the water column many times before being washed out with riverine outflow or being permanently buried in sediments (Wirth et al., 2013). This process left behind very little $\mathrm{Mn}$ and variable $\mathrm{Fe}$ in the sediments (see XRF scan, Figure 1). The transition from late glacial to lacustrine deposits is marked by a $20-\mathrm{cm}$ thick succession of Mn-oxide rich layers indicating the transition to seasonal water-column stratification. This Mn excursion has been explained by the accumulation of high concentrations of $\mathrm{Mn}^{2+}$ under reducing conditions, followed by rapid oxidation and burial during seasonal mixing events (Wirth et al., 2013). The radiocarbon ages of the lacustrine sediment succession from $780 \mathrm{~cm}$ to the sediment-water interface documents continuous sedimentation during the past $\sim 9.95$ kyrs (Figure 1). Based on this age-model we estimate the duration of the transition period with Mn-oxide layer deposition to have lasted between $\sim 9.95$ $(780 \mathrm{~cm})$ and $\sim 9.01(760 \mathrm{~cm})$ kyrs BP. Euxinic conditions persisted continuously since $9.01(760 \mathrm{~cm})$ kyrs BP.

\section{Strong Geochemical Gradients in Surface Sediments of Lake Cadagno}

High-resolution geochemical profiles of the top $40 \mathrm{~cm}$ reveal strong vertical gradients of both solid and dissolved compounds in surface sediments. The uppermost $0-10 \mathrm{~cm}$ of sediments are poorly consolidated, with porosities close to $99 \%$ and decreasing to $\sim 65 \%$ by $40 \mathrm{~cm}$ depth (Supplementary Table S1). The TOC content is $18 \mathrm{wt} \%$ at the surface and drops rapidly to $<5 \%$ within the top $20 \mathrm{~cm}$ (Figure 2A). The TIC is comparatively low and only a few values in the surface 
sediment are above the $0.8 \%$ reproducibility limit of the instrument, with a maximum of $2.0 \mathrm{wt} \%$ TIC in the top $0-1 \mathrm{~cm}$ (Supplementary Figure S3A). TN decreases in parallel with TOC, from $1.5 \mathrm{wt} \%$ at the surface to $0.2 \mathrm{wt} \%$ at $20 \mathrm{~cm}$. Over the same interval, $\mathrm{C}: \mathrm{N}$ ratios increase slightly, from 10.6 at the sediment surface to 11.7 at $20 \mathrm{~cm} \delta^{13} \mathrm{C}$-TOC values are lowest at the water column-sediment interface $\left(\delta^{13} \mathrm{C}=-35 \%\right.$ ) and become progressively less negative down to $40 \mathrm{~cm} \quad\left(\delta^{13} \mathrm{C}=-27 \%\right.$; Figure 2B). $\delta^{15} \mathrm{~N}$-TN values follow a steeper trend, increasing from $-1.28 \%$ at $0 \mathrm{~cm}$ to $2.67 \%$ at $15 \mathrm{~cm}$ depth. Together, these $\mathrm{C}$ and $\mathrm{N}$ values indicate the dominance of bacterioplankton-derived organic matter in surface sediments originating from photosynthetic primary producers in the chemocline (Posth et al., 2017).

The mineralization of organic matter is also evident from the increase in DIC and $\mathrm{NH}_{4}^{+}$concentrations with depth, from $2.9 \mathrm{mM}$ to $150 \mu \mathrm{M}$ at the surface to $9.1 \mathrm{mM}$ and $540 \mu \mathrm{M}$ at $40 \mathrm{~cm}$ depth, respectively (Figure 2C). $\mathrm{CH}_{4}$ concentrations also increase near-linearly with depth, reaching $\sim 2.5 \mathrm{mM}$ at $25 \mathrm{~cm}$, and continuing to increase more gradually below (Figure 2E). Neither $\mathrm{NO}_{3}{ }^{-}$nor $\mathrm{NO}_{2}{ }^{-}$were detected in surface sediments, but sulfate is depleted at approximately $40 \mathrm{~cm}$ depth with the accumulation of some free sulfide (Figure 2E). Due to the strong overlaps in $\mathrm{CH}_{4}$ and $\mathrm{SO}_{4}{ }^{2-}$ concentration profiles, we conclude that there is no true sulfate-methane transition zone. $\mathrm{PO}_{4}{ }^{3-}$ concentrations remain relatively constant between $100-200 \mu \mathrm{M}$ (Figure 2C) whereas dissolved $\mathrm{Mn}^{2+}$ and $\mathrm{Fe}^{2+}$ accumulate in the sulfide-free zone below $38 \mathrm{~cm}$ depth (Figure 2D). Above this depth, manganese- and iron monosulfides very likely precipitate with excess sulfide.

Solid-phase analyses revealed up to $\sim 300 \mu \mathrm{mol} \mathrm{S} / \mathrm{g}$ dry sediment at the sediment surface. This $S^{0}$ decreases steeply, stabilizing at low micromolar concentrations at $20 \mathrm{~cm}$ and below (Figure 2D). There is a parallel decrease of reactive Feoxides within the top $5 \mathrm{~cm}$ of sediment which does not preclude the persistence of $\mathrm{Mn}$-oxides or Fe-oxides that are not extracted with $0.25 \mathrm{mM} \mathrm{HCl}$, and thus not considered reactive based on this method. Nonetheless, XRF scanning data reveal the variable presence of some $\mathrm{Fe}$ in this surface sediment, but very little Mn (Figure 1).

\section{Geochemical Gradients Across the 13.5-kyr Subsurface Sedimentary Record}

The sediment depth interval $160-780 \mathrm{~cm}$ is characterized by intermediate porosities around 65\% (Supplementary Table S1) and low TOC (1.0-5.5\%) and TN (0.1-0.4\%) content (Figure 2A). There are no obvious depth-related trends except for an overall increase in TOC that is, most visible downcore of $500 \mathrm{~cm}$. In parallel, there is a slight increase in $\mathrm{C}: \mathrm{N}$ throughout this depth interval. Strong local differences can be attributed to sediment origin, with pelagic deposits being characterized by significantly ( $p<0.01$, Student t-test) lower C: $\mathrm{N}$ ratios $(10.6 \pm 1.4)$ than mass movement deposits $(13.8 \pm 1.7)$. The isotopic composition of TOC, but not TN, is also significantly lighter in lacustrine deposits $(p<0.01)$ than in turbidites.
There are relatively high concentrations of the reduced metals $\mathrm{Mn}^{2+}$ and $\mathrm{Fe}^{2+}$ as well as DIC in pore waters down to $\sim 670 \mathrm{~cm}$. These metal concentrations do not reflect the relative abundance or variability of total $\mathrm{Mn}$ and $\mathrm{Fe}$ in the solid phase (Figure 1). Both $\mathrm{NH}_{4}{ }^{+}$and $\mathrm{PO}_{4}{ }^{3-}$ exhibit broad peaks at $150-250 \mathrm{~cm}$ and 450-550. Methane exhibits a similar trend, reaching maximum concentrations of $4.5 \mathrm{mM}$ (Figure 2E), which is almost certainly an underestimate due to degassing evidenced by observed core expansion and bubble formation during sampling. Interestingly, the concentration minima of all of these compounds occur around $400-420 \mathrm{~cm}$ depth which corresponds to a thick massmovement deposit (Figure 1) also containing a local peak in TIC (1.8 wt\%; Supplementary Figure S3A). The low sulfate concentrations of $0-25 \mu \mathrm{M}$ throughout this depth interval are possibly due to contamination of subsurface porewaters with sulfate-rich bottom waters during sediment coring.

Below $670 \mathrm{~cm}$, porewater gradients of reduced metabolites mainly produced by microbial respiration reactions $\left(\mathrm{Fe}^{2+}, \mathrm{Mn}^{2+}\right.$, and $\left.\mathrm{CH}_{4}\right)$ and fermentation of $\mathrm{N}$-containing organic compounds $\left(\mathrm{NH}_{4}^{+}\right)$ decrease sharply, reaching the limit of detection by $790 \mathrm{~cm}$. Over the same depth interval, TOC (7.29\%) and TN (0.56\%) have local peaks at $670 \mathrm{~cm}$ that are followed by strong decreases to $0.36 \%$ TOC and $<0.02 \% \mathrm{TN}$ at $790 \mathrm{~cm}$. This decrease in TOC and TN contents coincides with a clear drop in the isotopic composition of TOC, from -27 to $-30 \%$ in mid column sediment above $670 \mathrm{~cm}$ to values as low as $-34.7 \%$ at $700 \mathrm{~cm}$, followed by an increase back to $\sim-28 \%$ at $790 \mathrm{~cm}$ and below (Figure 2B; Supplementary Figure S4). This local drop and subsequent increase in TOC isotopic values from 670 to $790 \mathrm{~cm}$ is accompanied by a slight gradual increase in TN isotopic values from $\sim 0.8$ to $2.0 \%$. The distinct chemical and isotopic changes between 670 and $790 \mathrm{~cm}$ appear to be associated with a lithological transition at $760-780 \mathrm{~cm}$ associated with a large $\mathrm{Mn} \backslash$ excursion (Figure 1), which corresponds to the anoxic-oxic transition period at 10.9-12.5 kyrs.

Late glacial sediments below $790 \mathrm{~cm}$ are characterized by a lower average porosity of 55\% (Supplementary Table S1) and extremely low TOC and TN content (Figure 2A), reflecting the low productivity and terrestrial organic matter input. In these deep sediments, sulfate concentrations increase steeply from $4 \mu \mathrm{M}$ at $780 \mathrm{~cm}$ to values of $100-210 \mu \mathrm{M}$ at $820 \mathrm{~cm}$ and below (Figure 2E). Active sulfate reduction is evidenced by a small peak in free sulfide $(9 \mu \mathrm{M})$ around $810 \mathrm{~cm}$, which likely reacts with $\mathrm{Mn}$ - or Fe-oxides there forming abundant $(22 \mu \mathrm{M})$ zero-valent sulfur (Figure 2D; Supplementary Figure S4).

\section{Relationship of Bacterial and Archaeal Abundances to Sediment Depth and Organic Carbon Content}

Bacterial and archaeal abundances based on 16S rRNA gene copy numbers are relatively stable at $7 \times 10^{8}$ copies/g wet sediment and $8 \times 10^{7}$ copies/g wet sediment, respectively, in the top $\sim 30 \mathrm{~cm}$ and gradually decrease by an order of magnitude down to the glacial sediment where they drastically drop (Figure 3A). There is only a very weak correlation between TOC content and total $16 \mathrm{~S}$ gene copy numbers (Supplementary Figure S5) indicating that other factors explain the variation in gene copy numbers in the mid- 

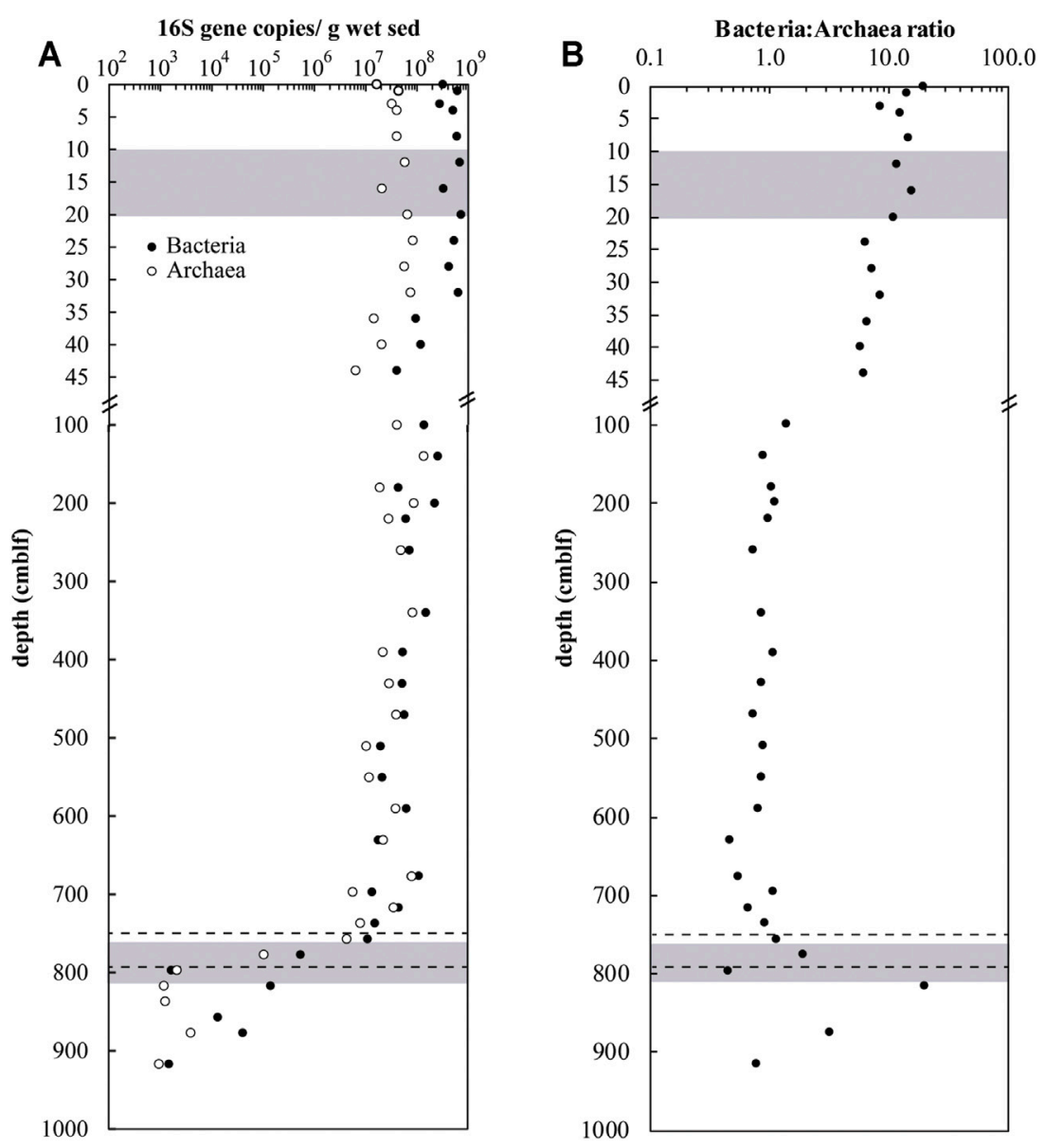

FIGURE 3 | (A) Archaeal and bacterial 16S rRNA gene copy numbers and (B) BARs vs. depth in sediment of Lake Cadagno. Note the break in the $y$-axis showing the upper $45-\mathrm{cm}$ of sediment in high resolution. Dashed lines denote the oxic-anoxic transition interval and shaded regions denote the sulfate depletion zones.

column sediment. Bacteria-to-Archaea $16 \mathrm{~S}$ rRNA gene copy ratios (BAR) are stable around $\sim 8-12$ in the top $20 \mathrm{~cm}$, and then decreases gradually to values around $\sim 1$ below $100 \mathrm{~cm}$ (Figure 3B). BAR values then increase again locally in the lower sulfate depletion zone and underlying oxidized sediment.

\section{Depositional History Determines Present-Day Microbial Community Zonation in Lake Cadagno}

According to a Principal Coordinates Analysis (PCoA) of Bacterial and Archaeal diversity, microbial communities cluster into four distinct groups according to sediment age and redox conditions during sediment deposition (Figure 4). These distinct groups can be classified into surface sediment $(0-44 \mathrm{~cm}$ depth), euxinic sediment $(150-760 \mathrm{~cm})$, redox transition sediment from the deep oxic-anoxic transition $(760-780 \mathrm{~cm})$, and late glacial sediment $(780-910 \mathrm{~cm})$.

These sediment groups, excluding the redox transition layer for which there is only one sample, are highly divergent from each other, sharing only $51(\sim 1.2 \%$ of all) Bacterial ZOTUs (the simplest taxonomic unit used here and defined by $97 \%$ sequence similarity) and $8(\sim 2.1 \%$ of all $)$ Archaeal ZOTUs. The slight differences exist between Bacterial (Figure 4A) and Archaeal (Figure 4B) community structure could be influenced by the very few number of archaeal sequences recovered at depth.

\section{Phylum- and Class-Level Variations in Bacterial Communities}

A total of 4,095 bacterial ZOTUs (2,053,665 reads) were recovered from the Lake Cadagno sediments. The vast majority, i.e., all but 358 bacterial ZOTUs, could be phylogenetically assigned at the phylum-level (Figure 5). Of the 59 assigned bacterial phyla, only four were recovered from all sediment depths (Actinobacteria, Atribacterota, Firmicutes, and Proteobacteria).

Bacterial diversity is greatest (comprising 1781-2205 distinct ZOTUs) in the surface sediment although at least some of these microorganisms, i.e., the photosynthetic Cyanobacteria, Chromatiales, and Chlorobi, may simply constitute a planktonic fraction that has settled from the water column and is not metabolically active in sediments (Ravasi et al., 



FIGURE 4 | Principal coordinates analysis plot of (A) bacterial and (B) archaeal community composition versus lithological drivers. Sample numbers indicate sampling depths and are color-coded according to sediment type. The five sediment samples of pelagic origin are circled to distinguish them from terrestrial or mass-movement deposits in squares.

2012). The Proteobacteria, which are the dominant phylum in surface sediments, are comprised mainly of Beta-, Delta-, Gamma-, and Epsilonproteobacteria with low percentages of Alphaproteobacteria. Besides Proteobacteria, dominant phyla in surface sediments include Parcubacteria, Chloroflexi, Caldiserica, Aminicenantes, and Bacteroidetes.

In the mid-column euxinic sediment, bacterial diversity is still high at the ZOTU level, ranging from 1800 ZOTUs in the upper $160 \mathrm{~cm}$ and decreasing to $\sim 800$ at $700 \mathrm{~cm}$. At the phylum level, Proteobacteria (of which almost all are Deltaproteobacteria), comprise between 8 and $15 \%$ of total bacterial sequences. Planctomycetes, Chloroflexi Atribacterota, Aminicenantes, and Acidobacteria increase notably in relative abundances. Of note, peaks in Spirochaetaceae and Anaerolinaceae abundances coincide with the upper and lower sulfate depletion zone. There are no differences in bacterial communities related to mass-movement events, terrestrial deposits, and lacustrine deposits (Figure 4).

The redox transition interval represents a transition not only in geochemical conditions but also in bacterial diversity. There is a small peak in diversity at the ZOTU level (957 OTUs) and a major shift in the dominant phyla, notably in the fraction of Aminicenantes sequences.

Compared to the overlying sediment, bacterial diversity in the deep glacial sediments is greatly reduced, with the total ZOTU numbers falling below 80 in parallel with the sharp decrease in total gene copy numbers (Figure 3). Proteobacteria are again the most abundant phylum, along with Actinobacteria. Among the Acidobacteria, Subgroup 6 and Solibacteres are most abundant, with the notable presence of one ZOTU affiliated to the genus Bryobacter, comprising $\sim 16 \%$ of bacterial reads at $890 \mathrm{~cm}$ depth. Another noteworthy finding is the locally high relative abundance of Candidate Phyla Radiation [Galena 15 (GAL15), Berkelbacteria, Katanobacteria (WWE3) and Dependentiae (TM6)]. Sequences of these phyla account for $10-25 \%$ of total bacterial reads in most glacial samples, similar to in the sulfate-rich surface sediments.

\section{Phylum- and Class-Level Variations in Archaeal Communities}

A total of 380 archaeal ZOTUs (4,506,390 reads) were recovered, which could all be classified into a total of 13 different phyla (Figure 6). Like Bacteria, Archaea are most diverse in surface sediment (Figure 6), affiliating with seven different phyla of which the Euryarchaeotal candidate order Thermoprofundales (also known as Marine Benthic Group D; class Thermoplasmata; Supplementary Figure S6) were most abundant (25-60\% of archaeal reads). In the glacial sediments, archaeal diversity is reduced to 1-2 phyla per depth, though the sample from $790 \mathrm{~cm}$ depth should be interpreted with caution because only 7 reads were obtained as opposed to $>35,000$ reads from other glacial samples. These deep glacial sediments were clearly dominated by aerobic Thaumarchaeaota affiliating with the ammonia-oxidizing Nitrososphaera.

\section{DISCUSSION}

Meromictic lakes are often cited as ancient ocean analogues and their sediments may retain geochemical signatures of past processes occurring in their anoxic waters. In this first complete biogeochemical characterization of the sediment record from the meromictic Lake Cadagno, we unveil both solid phase and porewater chemistry together with sedimentary microbial communities reflecting the first oxic, then suboxic, and finally anoxic $\sim 13.5 \mathrm{kyr}$ history of the lake. Moreover, the well-preserved stratigraphy of our piston cores provides an environmental reconstruction of the history of Lake Cadagno.

Discrete geochemical periods resulted in the deposition of distinct sediment types, beginning with white glacial till, rich in detrital clastic elements $(\mathrm{Na}, \mathrm{Al}, \mathrm{K})$ and poor in iron sulfides, which was deposited $~ 13.5-9.95$ kyrs, prior to the establishment of meromixis and euxinia in Lake Cadagno. The late glacial sediments are low in carbonate content and TOC thus supporting sparse microbial communities. Interestingly, porewaters in these sediments contain relatively high concentrations of $\mathrm{SO}_{4}{ }^{2-}, \mathrm{Mg}^{2+}$, and $\mathrm{Ca}^{2+}$ (Figure 2 and Supplementary Figure 3B), which is a first indication that this deeply buried sediment might be influenced by subterranean 




FIGURE 5 | Relative abundances of bacterial 16S rRNA gene sequences with depth. Sediment geological transitions are indicated on the right.

aquifers. Sediment deposited during the anoxic-oxic transition period $10.5-12.5 \mathrm{kyrs}(780-760 \mathrm{~cm})$ is rich in $\mathrm{Mn}-$, carbonate, and organic matter indicating a change in lake stratification conditions. The overlying $760 \mathrm{~cm}$ of euxinic sediment exhibits high accumulations of methane, DIC, and dissolved reduced metals resulting from the slow degradation of organic matter, except in very recent sediment dating to 220 years before present $(40-0 \mathrm{~cm})$ where steep chemical gradients indicate extremely rapid organic matter degradation and diagenesis.
In the following sections we present the relationships between dominant microbial communities and geochemistry in each of these sediment zones and individually discuss important microbial metabolisms involved in organic matter degradation including sulfur cycling, metal reduction, fermentation, and methanogenesis. From these analyses, we conclude that sediment redox conditions and organic matter quality are the main drivers of microbial community composition. We also highlight the novel discovery of an 


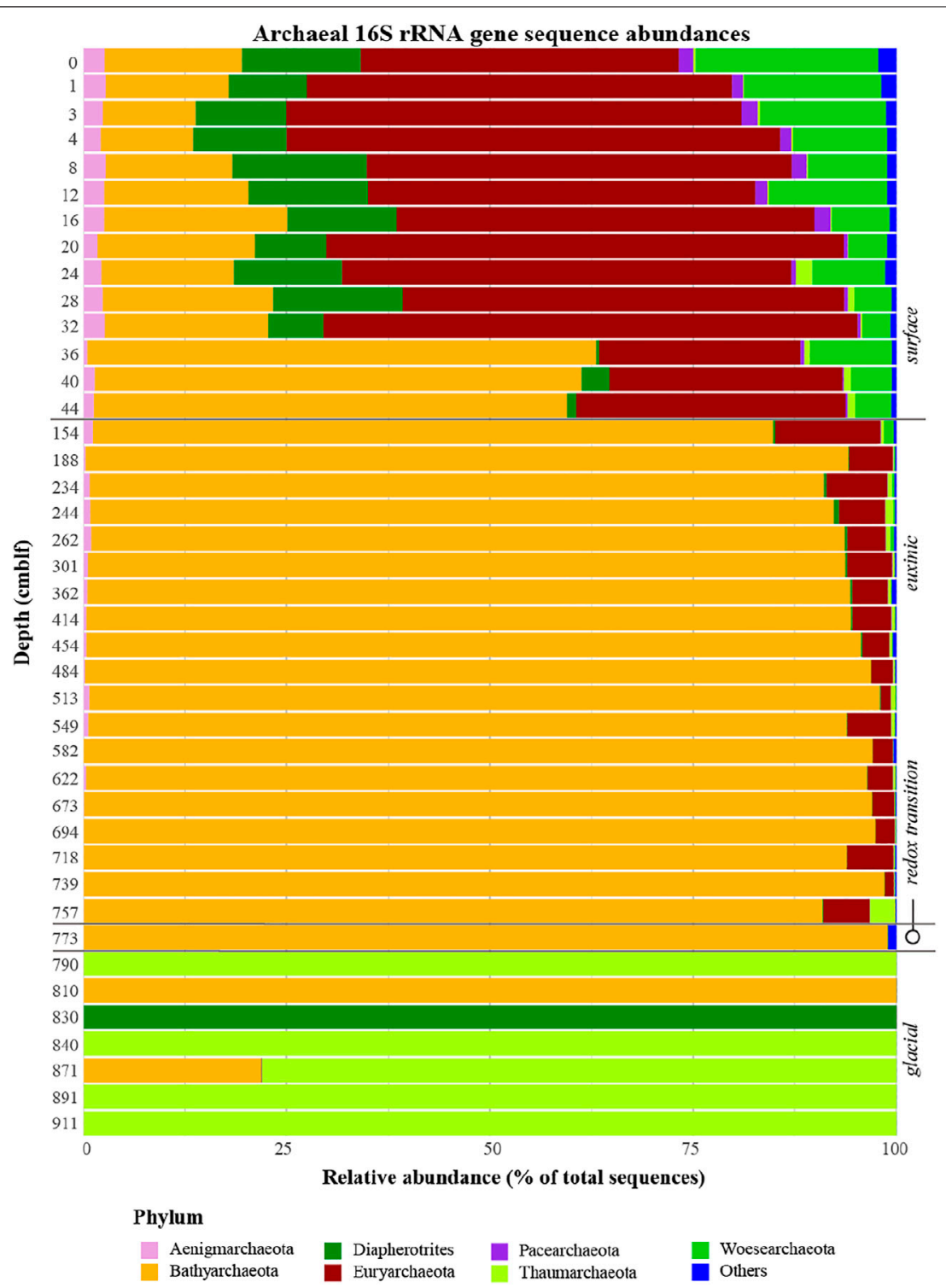

FIGURE 6 | Relative abundances of Archaeal 16S rRNA gene sequences with depth. Sediment geological transitions are indicated on the right.

oxidizing groundwater source generating a second redox transition zone in the deep subsurface with implications for deep sediment diagenesis.

\section{Extremely High Microbial Activity and Rapid Diagenesis in Surface Sediments}

Most of the microbial activity in the Lake Cadagno sediments occurs within the top $20 \mathrm{~cm}$ where, assuming constant organic carbon deposition rates, about $75 \%$ of the organic carbon that reaches the lake floor is remineralized (Figure 2A) and the highest microbial cell numbers are observed (Figure 3A). This very rapid degradation of organic matter suggests that TOC is highly reactive, which is not surprising given its mostly microbial and phytoplanktonic origin indicated by high $\mathrm{N}$-content and low $\delta^{13} \mathrm{C}$-TOC values (Figure 2A), and the short sinking depth of $<10 \mathrm{~m}$, mostly under anoxic conditions, before deposition on the lake floor.

In fact, organic matter quality appears to be one of the main drivers of microbial diversity (Figure 4). The presence of labile organic carbon in sulfate-rich surface sediments supports extremely diverse communities of microorganisms compared to euxinic sediments below $40 \mathrm{~cm}$. Surface sedimentary communities are remarkably similar to other organic-rich lacustrine (e.g., Wurzbacher et al., 2017; Rissanen et al., 2019; Han et al., 2020) and marine surface sediments (e.g., Chen et al., 2017; Orsi, 2018; Deng et al., 2020), despite the absence of an oxic-anoxic transition zone in Lake Cadagno sediments, with notably high abundances of Bacteroidetes, Verrucomicrobia, Alpha-, Beta-, and Gammaproteobacteria. In addition, the anoxic conditions in 
the water column and upper $20 \mathrm{~cm}$ favor Deltaproteobacteria and Chloroflexi, groups which are typically less common in surface sediments underlying oxic water. Archaea in the surface sediments belong to Thermoprofundales, Woesearchaeota, Diapherotrites, and Bathyarchaeota, groups that are ubiquitously distributed across organic-rich anoxic surface sediments.

\section{Euxinic and Redox Transition Sediment Geochemistry and Microbiology Reflect Depositional Conditions}

In the deeper euxinic sediment layers down to the glacial sediment, ${ }^{13} \mathrm{C}$-enriched TOC and higher $\mathrm{C}: \mathrm{N}$ ratios indicate the selective removal of isotopically light, N-rich, and presumably more labile organic matter of microbial and phytoplankton origin that dominates in shallow layers. This leaves behind more refractory organic matter with a higher terrestrial component in deeper layers. Depth-profiles of Bacteria and Archaea reflect this trend as the mid-column sediments are dominated by clades specialized in the fermentative and acetogenic degradation of complex organic carbon substrates such as Dehalococcoidia, Atribacterota, Aminicenantes, and Bathyarchaeota (Farag et al., 2014; Youssef et al., 2015; Nobu et al., 2016; Zhou et al., 2018), groups that commonly dominate energy-depleted lacustrine and marine subsurface sediments [e.g., (Vuillemin et al., 2018; Deng et al., 2020)]. Overall, carbon turnover at depth is likely extremely slow as reflected in the absence of a clear TOC depth gradient. Although microbial degradation of terrestrial- and pelagic lacustrine-derived organic matter are thought to be differential, we observe no clear shift in microbial community structure between lacustrine-dominated layers and turbiditic layers with elevated terrestrial organic matter inputs (Figure 4). This matches previous research on Holocene marine sediments [e.g., (Torti et al., 2018)], and suggests overprinting of terrestrial microbial DNA signatures by those microbial taxa that are typical of anoxic subsurface sediments.

The Mn-rich layers just below $(760-780 \mathrm{~cm})$ correspond to the redox transition period from 12.5 to $10.9 \mathrm{kyrs}$. The sediment region corresponding to the onset of complete anoxia at $10.9 \mathrm{kyrs}$ $(760 \mathrm{~cm})$ is characterized by a higher content of TOC (Figure 2A), which was likely preserved due to decreased remineralization during anoxia, enhanced primary productivity due to warming and deglaciation. At that time, the activation of subaquatic springs combined with increased light availability (due to spring thawing) may have led to higher nutrient availability and primary productivity in the photic zone thus increasing the benthic oxygen demand leading to bottom water anoxia and enhancing organic carbon preservation (Wirth et al., 2013). The accompanying excursion to light $\delta^{13} \mathrm{C}$ values of $-35 \%$, similar to the surface sediments, indicates material of pelagic origin (Posth et al., 2017).

The higher TOC content in the redox transition zone appears to support greater microbial cell numbers. Although only one sample was sequenced from within these transition sediments, the microbial diversity was strikingly different from the underlying late glacial sediments and the overlying euxinic sediment (Figure 4). This microbial community shift may be associated with differences in TOC quantity and quality, or the onset of oxidizing conditions not only at the time of deposition, but also in contemporary porewater gradients.

\section{Evidence for a Deep, Oxidizing Source Below the Anoxic Sediment Column}

Sediments situated below $780 \mathrm{~cm}$ depth are characterized by extremely low cell numbers (Figure 3A), likely reflecting their low TOC content. Increasing ratios of Bacteria to Archaea in these sediments may reflect oxidizing conditions (Chen et al., 2017; Deng et al., 2020). Similar sediment sequences of sulfidic sediment with underlying oxidized sediment can be found in euxinic basins such as the Black Sea recording a transition from oxic to anoxic conditions (Jørgensen et al., 2004). These ancient, deeply buried sediments can be subject to contemporary influences such as downwards-seeping sulfate in the Black Sea. In Lake Cadagno, sulfate is consumed in the upper $20 \mathrm{~cm}$ of sediment and the deep, ancient sediments are instead impacted by a deep source of sulfate. An upwards sulfate flux of about $6 \mu \mathrm{mol} \mathrm{m} \mathrm{m}^{-2} \mathrm{~d}^{-1}$ overlaps with a downwards flux of methane of $96 \mu \mathrm{mol} \mathrm{m} \mathrm{m}^{-1}$ at around $770 \mathrm{~cm}$ depth. These fluxes are 1-2 orders of magnitude lower than at the surface depletion zone, partly due to the lower porosity and permeability of clastic clays, and partly due to the decrease in reactivity of the organic matter available for microbial methanogenesis. The huge imbalance between electron donors and acceptors (the stoichiometry of anaerobic methane oxidation is $1 \mathrm{~mol} \mathrm{CH}_{4}$ to $1 \mathrm{~mol} \mathrm{SO}_{4}{ }^{2-}$ ) at the deep sulfate depletion zone indicates that other oxidants are available to consume methane, which does not penetrate into the glacial sediments. An upwards flux of oxygen of $192 \mu \mathrm{mol} \mathrm{m}{ }^{-2} \mathrm{~d}^{-1}$, for example, could theoretically drive the aerobic oxidation of methane diffusing into the glacial sediments and account for the absence of free sulfide, $\mathrm{Fe}^{2+}$ and $\mathrm{Mn}^{2+}$ below $820 \mathrm{~cm}$. In fact, aerobic Thaumarchaeota and members of the obligately aerobic chemo-organotrophic Solibacteres lineage Bryobacter (Kulichevskaya et al., 2010) are present at depth. A deep source of dissolved $\mathrm{O}_{2}$ could also explain the occurrence of common nano-sized bacteria of the Candidate Phylum Radiation (GAL15, Berkelbacteria, Kazanbacteria, SR1, TM6; e.g.) many of which possess reduced genomes and are believed to depend on aerobic eukaryotic hosts such as protists for survival (Castelle et al., 2018).

Together, our biogeochemical data suggest the presence of an oxidizing groundwater source, likely containing $\mathrm{O}_{2}$, located at the base of the Lake Cadagno sediment column. Although it has previously been found that ancient, oxic water can be trapped in pore spaces of clay-rich glacial till, as in Baltic Sea sediments (Jørgensen et al., 2020), diffusive modeling of the Lake Cadagno system (Supplementary Figure S7) reveals that a constant supply of oxidants via an aquifer is required to maintain the geochemical gradients observed. A subsurface aquifer which feeds the underwater springs at $8-10 \mathrm{~m}$ water depth (Del Don et al., 2001) could diffuse and/or advect into overlying non-cohesive 
glacial sediments transporting electron acceptors and even microbial cells there.

The presence of a deep, oxidizing groundwater source generates an inverse redox gradient and fresh source of electron acceptors deep within the sediment. Such an inverse gradient has been reported from marine sediment columns, including locations on the Peruvian Shelf and Equatorial Pacific (D'Hondt et al., 2004) and the Baltic Sea (Jørgensen et al., 2020), and may also be a widespread phenomenon below porous lake sedimentary systems. Although lower fluxes of methane and microbial cell numbers indicate that microbial activity is less than at the surface, deep sources of electron acceptors could contribute to the remineralization of deeply buried, early Holocene organic matter.

\section{Surprising Potential for Sulfur Cycling in the Deep Sediments of Lake Cadagno}

Sulfate reduction occurs prior to $\mathrm{Mn}$ - and Fe-reduction in the uppermost sediment layers and consumes sulfate completely within the top $20 \mathrm{~cm}$. Abundances of known sulfate-reducing Deltaproteobacteria (Desulfobacca, Desulfomonile, Desulfatiglans, and Desulfatirhabdium) coincide with the decreasing concentration of sulfate. Below the sulfate depletion zone, the abundance of potential sulfur-cycling taxa, in particular Caldiserica, in the mid-column sediment suggests that internal cycling of sulfur may be possible long after measurable sulfate and solid-extractable sulfur have disappeared (Wasmund et al., 2016; Anantharaman et al., 2018). This is consistent with previous findings of active microbial sulfur cycling in sulfate-depleted sediments (Pellerin et al., 2018) and would be worthy of future investigation.

The sulfate penetration depth is regulated by both sulfate concentration, organic carbon reactivity, and sediment deposition rates. In Lake Cadagno, the relatively shallow sulfate depletion zone is in part due to sulfate limitation, in contrast to euxinic basins such as the Black Sea and the Cariaco Basin, where the sulfate penetration depth is on the order of several meters (Werne et al., 2003; Jørgensen et al., 2004). Low organic matter deposition rates lead to a reduction in microbial activity and subsequent downward migration of the sulfatemethane transition zone (SMTZ). The relatively low sediment deposition rates $\left(2-2.5 \mathrm{~mm} \mathrm{yr}^{-1}\right.$ ) in Lake Cadagno (Wirth et al., 2013; Bueche and Junier, 2016) compared to the Black Sea [50 $\mathrm{mm} \mathrm{yr}^{-1}$; (Henkel et al., 2012)] and the Cariaco Basin [30 $\mathrm{mm} \mathrm{yr}^{-1}$; (Werne et al., 2003)] do not fit this trend and may therefore depend on quality and not quantity of the organic matter supply.

In the Lake Cadagno sediment, methanogenesis is initiated regardless of the presence of sulfate and thus there is no true SMTZ. The strong overlaps in $\mathrm{CH}_{4}$ and $\mathrm{SO}_{4}{ }^{2-}$ concentration profiles, and the near-linear $\mathrm{CH}_{4}$ gradient, which results in methane depletion only at the sediment surface, suggest that most methane in the upper $25 \mathrm{~cm}$ is diffusing upward from deeper layers, and that $\mathrm{CH}_{4}$ is mainly consumed at the sediment surface and water column. This linear methane gradient (Figure 2E) along with the failure to detect key anaerobic methane-oxidizing archaea indicates that there is minimal anaerobic oxidation of methane (AOM) occurring in these sediments (Schubert et al., 2011). Instead, sulfate reducers appear to preferably degrade energy-rich fresh organic matter over energy-poor methane.

\section{Metal Reduction, Fermentation, and Methanogenesis Are Involved in the Slow Remineralization of Deeply Buried Carbon}

It has previously been shown that $\mathrm{Mn}$ and $\mathrm{Fe}$ in the Lake Cadagno sediments exhibit only weak correlations to other elements and are not attributable to specific lacustrine or terrestrial lithologies (Wirth et al., 2013). This is because these largely terrestrial-derived metals are involved in redox and diagenetic recycling processes within sediments and pore waters that erase source-related connections to other elements. Indeed, the accumulation of high concentrations of dissolved $\mathrm{Mn}^{2+}$ and $\mathrm{Fe}^{2+}$ in porewaters below $40 \mathrm{~cm}$ (Figure 2D) suggest that microbial metal reduction is an important driver of organic carbon remineralization in the euxinic sediments of Lake Cadagno. Semi-quantitative XRF measurements of $\mathrm{Fe}$ and $\mathrm{Mn}$ (Figure 1) indicate that total $\mathrm{Fe}$ is much more abundant than Mn. Yet, the higher porewater concentrations of $\mathrm{Mn}^{2+}$ (Figure 2D) suggest that $\mathrm{Mn}(\mathrm{IV})$ is preferentially reduced over $\mathrm{Fe}(\mathrm{III})$, possibly owing to its higher energetic yields, and/or because $\mathrm{Fe}^{2+}$ precipitates more efficiently with sulfide than $\mathrm{Mn}^{2+}$.

While both $\mathrm{Mn}$ - and Fe-oxides may be abiotically reduced by sulfide in surface sediments (Figure 2E), active microbial metal reduction is likely occurring in the sulfate-depleted deep sediments of Lake Cadagno. Despite being commonly isolated from diverse environments including the deep subsurface (Coates et al., 1996), we recovered only four ZOTUs ( $>0.5 \%$ abundant) affiliating with the ironreducing genus Geobacter (Desulfuromonadales). Most known sulfur/sulfate reducers are also facultative metal reducers and may thus indirectly or directly drive $\mathrm{Fe}$ - and Mn-oxide reduction. Nonetheless, sequences belonging to known facultative metal reducing families such as Desulfobulbaceae, Desulfovibirionaceae, and Desulfobacteraceae are mostly absent from the deep sediment. Together, our data suggest that the intensely studied model metal-reducers such as Geobacter spp., are of relatively minor importance in these deep sediments compared to more versatile microorganisms, including fermenters and possibly unknown groups as has been shown for marine suboxic sediments (Reyes et al., 2016).

Fermentative and/or acetogenic taxa (such as Bacteroidetes, Chloroflexi, Spirochaetes, Anaerolineae, Atribacteria, and Aminicenantes) are common throughout the Lake Cadagno sediments and some of these taxa may also be linked to methanogenesis. Despite high methane concentrations in the Lake Cadagno sediments, however, methanogen populations detected by $16 \mathrm{~S}$ rRNA gene sequencing represent a very minor fraction of the microbial community. This observation, which is common to low-energy environments, including methane-rich 
lake sediments (Han et al., 2020), can be explained by small populations of methanogens subsisting at the biological energy quantum and producing high accumulations of methane over time (Hoehler et al., 2001; Orsi et al., 2020). We detected only one potential group of methanogens (Supplementary Figure S6) and no methanotrophs of the ANME-2d class nor of AOM-associated archaea which have previously been detected in Lake Cadagno sediments (Schubert et al., 2011; Su et al., 2019), but other methane-cycling archaea may simply not have been covered by our $16 \mathrm{~S}$ rRNA gene survey because they generally exhibit low abundances.

\section{DATA AVAILABILITY STATEMENT}

The datasets presented in this study can be found in online repositories. The names of the repository/repositories and accession number(s) can be found below: NCBI (accession: PRJNA752598).

\section{AUTHOR CONTRIBUTIONS}

JB coordinated sampling expedition, analyzed data, and wrote the manuscript. MTL performed the geochemical analyses and EL performed molecular analyses with assistance from XH. HV and MM performed sedimentological analyses and generated an age model for the sediment record. NG and AG assisted in the field

\section{REFERENCES}

Anantharaman, K., Hausmann, B., Jungbluth, S. P., Kantor, R. S., Lavy, A., Warren, L. A., et al. (2018). Expanded Diversity of Microbial Groups that Shape the Dissimilatory Sulfur Cycle. Isme J. 12, 1715-1728. doi:10.1038/s41396-018-0078-0

Ariztegui, D., Thomas, C., and Vuillemin, A. (2015). Present and Future of Subsurface Biosphere Studies in Lacustrine Sediments through Scientific Drilling. Int. J. Earth Sci. (Geol Rundsch) 104, 1655-1665. doi:10.1007/ s00531-015-1148-4

Bak, F., and Pfennig, N. (1991). Microbial Sulfate Reduction in Littoral Sediment of Lake Constance. FEMS Microbiol. Lett. 85, 31-42. doi:10.1111/j.15746968.1991.tb04695.x

Blaauw, M., and Christen, J. A. (2011). Flexible Paleoclimate Age-Depth Models Using an Autoregressive Gamma Process. Bayesian Anal. 6, 457-474. doi:10.1214/11-BA61810.1214/ba/1339616472

Blees, J., Niemann, H., Wenk, C. B., Zopfi, J., Schubert, C. J., Kirf, M. K., et al. (2014). Micro-aerobic Bacterial Methane Oxidation in the Chemocline and Anoxic Water Column of Deep South-Alpine Lake Lugano (Switzerland). Limnol. Oceanogr. 59, 311-324. doi:10.4319/lo.2014.59.2.0311

Boudreau, B. P. (1997). Diagenetic Models and Their Implementation. Berlin: Springer.

Bueche, M., and Junier, P. (2016). Effect of Organic Carbon and Metal Accumulation on the Bacterial Communities in Sulphidogenic Sediments. Environ. Sci. Pollut. Res. 23, 10443-10456. doi:10.1007/ s11356-016-6056-z

Cadillo-Quiroz, H., Bräuer, S., Yashiro, E., Sun, C., Yavitt, J., and Zinder, S. (2006). Vertical Profiles of Methanogenesis and Methanogens in Two Contrasting Acidic Peatlands in central New York State, USA. Environ. Microbiol. 8, 1428-1440. doi:10.1111/j.1462-2920.2006.01036.x

Canfield, D. E. (1998). A New Model for Proterozoic Ocean Chemistry. Nature 396, 450-453. doi:10.1038/24839 and collected in situ data. SB contributed isotope analyses. CS and GS contributed methane and DIC analyses. MAL supervised the project and assisted with phylogenetic analyses.

\section{FUNDING}

This study was supported by the Swiss National Science Foundation (SNF) grant No. 182096 (M.A.L.).

\section{ACKNOWLEDGMENTS}

We thank the entire 2019 Cadagno sampling crew for assistance in the field, and especially the Alpine Biology Center Foundation (Switzerland) for use of its research facilities. We also acknowledge Iso Christl, Madalina Jaggi, Rachele Ossola, Annika Fiskal, and Clemens Glombitza for their support with chemical analyses along with Longhui Deng for support with bioinformatic analyses. Giulia Ceriotti is acknowledged for her modeling of the glacial porewater reservoir.

\section{SUPPLEMENTARY MATERIAL}

The Supplementary Material for this article can be found online at: https:/www.frontiersin.org/articles/10.3389/feart.2021.754888/ full\#supplementary-material

Capone, D. G., and Kiene, R. P. (1988). Comparison of Microbial Dynamics in marine and Freshwater Sediments: Contrasts in Anaerobic Carbon Catabolism1. Limnol. Oceanogr. 33, 725-749. doi:10.4319/ lo.1988.33.4part2.0725

Carlton, R. G., Walker, G. S., Klug, M. J., and Wetzel, R. G. (1989). Relative Values of Oxygen, Nitrate, and Sulfate to Terminal Microbial Processes in the Sediments of Lake Superior. J. Great Lakes Res. 15, 133-140. doi:10.1016/ S0380-1330(89)71467-2

Castelle, C. J., Brown, C. T., Anantharaman, K., Probst, A. J., Huang, R. H., and Banfield, J. F. (2018). Biosynthetic Capacity, Metabolic Variety and Unusual Biology in the CPR and DPANN Radiations. Nat. Rev. Microbiol. 16, 629-645. doi:10.1038/s41579-018-0076-2

Chen, X., Andersen, T. J., Morono, Y., Inagaki, F., Jørgensen, B. B., and Lever, M. A. (2017). Bioturbation as a Key Driver behind the Dominance of Bacteria over Archaea in Near-Surface Sediment. Sci. Rep. 7, 2400. doi:10.1038/s41598-01702295-x

Claesson, M. J., O’Sullivan, O., Wang, Q., Nikkilä, J., Marchesi, J. R., Smidt, H., et al. (2009). Comparative Analysis of Pyrosequencing and a Phylogenetic Microarray for Exploring Microbial Community Structures in the Human Distal Intestine. PLoS One 4, e6669. doi:10.1371/journal.pone.0006669

Cline, J. D. (1969). Spectrophotometric Determination of Hydrogen Sulfide in Natural Waters1. Limnol. Oceanogr. 14, 454-458. doi:10.4319/lo.1969.14.3.0454

Coates, J. D., Phillips, E. J., Lonergan, D. J., Jenter, H., and Lovley, D. R. (1996). Isolation of Geobacter Species from Diverse Sedimentary Environments. Appl. Environ. Microbiol. 62, 1531-1536. doi:10.1128/aem.62.5.1531-1536.1996

D’Hondt, S., Jørgensen, B. B., Miller, D. J., Batzke, A., Blake, R., Cragg, B. A., et al. (2004). Distributions of Microbial Activities in Deep Subseafloor Sediments. Science 306, 2216-2221. doi:10.1126/science.1101155

Dean, W. E., and Gorham, E. (1998). Magnitude and Significance of Carbon Burial in Lakes, Reservoirs, and Peatlands. Geol 26, 535-538. doi:10.1130/00917613(1998)026<0535:masocb $>2.3 . c 0 ; 2$ 
Del Don, C., Hanselmann, K. W., Peduzzi, R., and Bachofen, R. (2001). The Meromictic alpine Lake Cadagno: Orographical and Biogeochemical Description. Aquat. Sci. 63, 70-90. doi:10.1007/PL00001345

Deng, L., Bölsterli, D., Kristensen, E., Meile, C., Su, C.-C., Bernasconi, S. M., et al. (2020). Macrofaunal Control of Microbial Community Structure in continental Margin Sediments. Proc. Natl. Acad. Sci. USA 117, 15911-15922. doi:10.1073/ pnas. 1917494117

Farag, I. F., Davis, J. P., Youssef, N. H., and Elshahed, M. S. (2014). Global Patterns of Abundance, Diversity and Community Structure of the Aminicenantes (Candidate Phylum OP8). PLoS One 9, e92139. doi:10.1371/ journal.pone.0092139

Glombitza, C., Stockhecke, M., Schubert, C. J., Vetter, A., and Kallmeyer, J. (2013). Sulfate Reduction Controlled by Organic Matter Availability in Deep Sediment Cores from the saline, Alkaline Lake Van (Eastern Anatolia, Turkey). Front. Microbiol. 4, 209. doi:10.3389/fmicb.2013.00209

Han, X., Schubert, C. J., Fiskal, A., Dubois, N., and Lever, M. A. (2020). Eutrophication as a Driver of Microbial Community Structure in lake Sediments. Environ. Microbiol. 22, 3446-3462. doi:10.1111/1462-2920.15115

Hansel, C. M., Lentini, C. J., Tang, Y., Johnston, D. T., Wankel, S. D., and Jardine, P. M. (2015). Dominance of Sulfur-Fueled Iron Oxide Reduction in LowSulfate Freshwater Sediments. Isme J. 9, 2400-2412. doi:10.1038/ ismej. 2015.50

Henkel, S., Mogollón, J. M., Nöthen, K., Franke, C., Bogus, K., Robin, E., et al. (2012). Diagenetic Barium Cycling in Black Sea Sediments - A Case Study for Anoxic marine Environments. Geochimica et Cosmochimica Acta 88, 88-105. doi:10.1016/j.gca.2012.04.021

Herlemann, D. P., Labrenz, M., Jürgens, K., Bertilsson, S., Waniek, J. J., and Andersson, A. F. (2011). Transitions in Bacterial Communities along the 2000 Km Salinity Gradient of the Baltic Sea. Isme J. 5, 1571-1579. doi:10.1038/ ismej.2011.41

Hoehler, T. M., Alperin, M. J., Albert, D. B., and Martens, C. S. (2001). Apparent Minimum Free Energy Requirements for Methanogenic Archaea and SulfateReducing Bacteria in an Anoxic marine Sediment. FEMS Microbiol. Ecol. 38, 33-41. doi:10.1111/j.1574-6941.2001.tb00879.x

Jørgensen, B. B., Andrén, T., and Marshall, I. P. G. (2020). Sub-seafloor Biogeochemical Processes and Microbial Life in the Baltic Sea. Environ. Microbiol. 22, 1688-1706. doi:10.1111/1462-2920.14920

Jørgensen, B. B., Böttcher, M. E., Lüschen, H., Neretin, L. N., and Volkov, I. I. (2004). Anaerobic Methane Oxidation and a Deep H2S Sink Generate Isotopically Heavy Sulfides in Black Sea Sediments. Geochimica et Cosmochimica Acta 68, 2095-2118. doi:10.1016/j.gca.2003.07.017

Kallmeyer, J., Pockalny, R., Adhikari, R. R., Smith, D. C., and D'Hondt, S. (2012). Global Distribution of Microbial Abundance and Biomass in Subseafloor Sediment. Proc. Natl. Acad. Sci. 109, 16213-16216. doi:10.1073/ pnas. 1203849109

Karstens, L., Asquith, M., Davin, S., Fair, D., Gregory, W. T., Wolfe, A. J., et al. (2019). Controlling for Contaminants in Low-Biomass 16S rRNA Gene Sequencing Experiments. $m$ Systems 4, e00290. doi:10.1128/mSystems.00290-19

Kempers, A. J., and Kok, C. J. (1989). Re-examination of the Determination of Ammonium as the Indophenol Blue Complex Using Salicylate. Analytica Chim. Acta 221, 147-155. doi:10.1016/S0003-2670(00)81948-0

Kulichevskaya, I. S., Suzina, N. E., Liesack, W., and Dedysh, S. N. (2010). Bryobacter Aggregatus Gen. nov., Sp. nov., a Peat-Inhabiting, Aerobic Chemo-Organotroph from Subdivision 3 of the Acidobacteria. Int. J. Syst. Evol. Microbiol. 60, 301-306. doi:10.1099/ijs.0.013250-0

Lever, M. A., Torti, A., Eickenbusch, P., Michaud, A. B., Å antl-Temkiv, T., and Jã, rgensen, B. B. (2015). A Modular Method for the Extraction of DNA and RNA, and the Separation of DNA Pools from Diverse Environmental Sample Types. Front. Microbiol. 6, 476. doi:10.3389/ fmicb.2015.00476

Lovley, D. R., and Phillips, E. J. P. (1986). Organic Matter Mineralization with Reduction of Ferric Iron in Anaerobic Sediments. Appl. Environ. Microbiol. 51, 683-689. doi:10.1128/aem.51.4.683-689.1986

Nobu, M. K., Dodsworth, J. A., Murugapiran, S. K., Rinke, C., Gies, E. A., Webster, G., et al. (2016). Phylogeny and Physiology of Candidate Phylum 'Atribacteria' (OP9/JS1) Inferred from Cultivation-independent Genomics. Isme J. 10, 273-286. doi:10.1038/ismej.2015.97
Ohkuma, M., and Kudo, T. (1998). Phylogenetic Analysis of the Symbiotic Intestinal Microflora of the termiteCryptotermes Domesticus. FEMS Microbiol. Lett. 164, 389-395. doi:10.1111/j.1574-6968.1998.tb13114.x

Onstott, T. C., Phelps, T. J., Kieft, T., Colwell, F. S., Balkwill, D. L., Fredrickson, J. K., et al. (1999). "A Global Perspective on the Microbial Abundance and Activity in the Deep Subsurface," in Enigmatic Microorganisms And Life In Extreme Environments Cellular Origin and Life in Extreme Habitats. Editor J. Seckbach (Dordrecht, Netherlands: Springer), 487-500. doi:10.1007/978-94011-4838-2_38

Orsi, W. D. (2018). Ecology and Evolution of Seafloor and Subseafloor Microbial Communities. Nat. Rev. Microbiol. 16, 671-683. doi:10.1038/s41579-0180046-8

Orsi, W. D., Schink, B., Buckel, W., and Martin, W. F. (2020). Physiological Limits to Life in Anoxic Subseafloor Sediment. FEMS Microbiol. Rev. 44, 219-231. doi:10.1093/femsre/fuaa004

Parkes, R. J., Webster, G., Cragg, B. A., Weightman, A. J., Newberry, C. J., Ferdelman, T. G., et al. (2005). Deep Sub-seafloor Prokaryotes Stimulated at Interfaces over Geological Time. Nature 436, 390-394. doi:10.1038/ nature 03796

Pellerin, A., Antler, G., Røy, H., Findlay, A., Beulig, F., Scholze, C., et al. (2018). The Sulfur Cycle below the Sulfate-Methane Transition of marine Sediments. Geochimica et Cosmochimica Acta 239, 74-89. doi:10.1016/ j.gca.2018.07.027

Posth, N. R., Bristow, L. A., Cox, R. P., Habicht, K. S., Danza, F., Tonolla, M., et al. (2017). Carbon Isotope Fractionation by Anoxygenic Phototrophic Bacteria in Euxinic Lake Cadagno. Geobiology 15, 798-816. doi:10.1111/ gbi. 12254

Poulton, S. W., Fralick, P. W., and Canfield, D. E. (2004). The Transition to a Sulphidic Ocean 1.84 Billion Years Ago. Nature 431, 173-177. doi:10.1038/ nature02912

Ravasi, D. F., Peduzzi, S., Guidi, V., Peduzzi, R., Wirth, S. B., Gilli, A., et al. (2012). Development of a Real-Time PCR Method for the Detection of Fossil 16S rDNA Fragments of Phototrophic Sulfur Bacteria in the Sediments of Lake Cadagno. Geobiology 10, 196-204. doi:10.1111/j.14724669.2012.00326.x

Reimer, P. J., Bard, E., Bayliss, A., Beck, J. W., Blackwell, P. G., Ramsey, C. B., et al. (2013). IntCal13 and Marine13 Radiocarbon Age Calibration Curves 050,000 Years Cal BP. Radiocarbon 55, 1869-1887. doi:10.2458/ azu_js_rc.55.16947

Reyes, C., Dellwig, O., Dähnke, K., Gehre, M., Noriega-Ortega, B. E., Böttcher, M. E., et al. (2016). Bacterial Communities Potentially Involved in Iron-Cycling in Baltic Sea and North Sea Sediments Revealed by Pyrosequencing. FEMS Microbiol. Ecol. 92, fiw054. doi:10.1093/femsec/fiw054

Rissanen, A. J., Peura, S., Mpamah, P. A., Taipale, S., Tiirola, M., Biasi, C., et al. (2019). Vertical Stratification of Bacteria and Archaea in Sediments of a Small Boreal Humic lake. FEMS Microbiol. Lett. 366. doi:10.1093/ femsle/fnz044

Roden, E. E., and Wetzel, R. G. (1996). Organic Carbon Oxidation and Suppression of Methane Production by Microbial Fe(III) Oxide Reduction in Vegetated and Unvegetated Freshwater Wetland Sediments. Limnol. Oceanogr. 41, 1733-1748. doi:10.4319/lo.1996.41.8.1733

Schink, B. (1997). Energetics of Syntrophic Cooperation in Methanogenic Degradation. Microbiol. Mol. Biol. Rev. 61, 262-280. doi:10.1128/ mmbr.61.2.262-280.1997

Schubert, C. J., Vazquez, F., Lösekann-Behrens, T., Knittel, K., Tonolla, M., and Boetius, A. (2011). Evidence for anaerobic oxidation of methane in sediments of a freshwater system (Lago di Cadagno). FEMS Microbiol. Ecol. 76, 26-38. doi:10.1111/j.1574-6941.2010.01036.x

Sheik, C. S., Reese, B. K., Twing, K. I., Sylvan, J. B., Grim, S. L., Schrenk, M. O., et al. (2018). Identification and Removal of Contaminant Sequences from Ribosomal Gene Databases: Lessons from the Census of Deep Life. Front. Microbiol. 9, 840. doi: $10.3389 /$ fmicb.2018.00840

Sørensen, K. B., and Teske, A. (2006). Stratified Communities of Active Archaea in Deep Marine Subsurface Sediments. Appl. Environ. Microbiol. 72, 4596-4603. doi:10.1128/AEM.00562-06

Stookey, L. L. (1970). Ferrozine-a New Spectrophotometric Reagent for Iron. Anal. Chem. 42, 779-781. doi:10.1021/ac60289a016 
Su, G., Zopfi, J., Yao, H., Steinle, L., Niemann, H., and Lehmann, M. F. (2019). Manganese/iron-supported Sulfate-dependent Anaerobic Oxidation of Methane by Archaea in lake Sediments. Limnol Oceanogr 65, 863-875. doi:10.1002/lno.11354

Thomas, C., Francke, A., Vogel, H., Wagner, B., and Ariztegui, D. (2020). Weak Influence of Paleoenvironmental Conditions on the Subsurface Biosphere of lake Lake Ohrid over the Last 515 Ka. Microorganisms 8 (11), 1736. doi:10.31223/osf.io/jmye6

Thomas, C., Ionescu, D., and Ariztegui, D. (2014). Archaeal Populations in Two Distinct Sedimentary Facies of the Subsurface of the Dead Sea. Mar. Genomics 17, 53-62. doi:10.1016/j.margen.2014.09.001

Torti, A., Jørgensen, B. B., and Lever, M. A. (2018). Preservation of Microbial DNA in marine Sediments: Insights from Extracellular DNA Pools. Environ. Microbiol. 20, 4526-4542. doi:10.1111/1462-2920.14401

Urban, N. R., Brezonik, P. L., Baker, L. A., and Sherman, L. A. (1994). Sulfate Reduction and Diffusion in Sediments of Little Rock Lake, Wisconsin. Limnol. Oceanogr. 39, 797-815. doi:10.4319/lo.1994.39.4.0797

Vuillemin, A., Ariztegui, D., Horn, F., Kallmeyer, J., and Orsi, W. D. (2018). Microbial Community Composition along a 50 000-year Lacustrine Sediment Sequence. FEMS Microbiol. Ecol. 94, fiy029. doi:10.1093/ femsec/fiy029

Vuillemin, A., Friese, A., Alawi, M., Henny, C., Nomosatryo, S., Wagner, D., et al. (2016). Geomicrobiological Features of Ferruginous Sediments from Lake Towuti, Indonesia. Front. Microbiol. 7, 1007. doi:10.3389/ fmicb.2016.01007

Wang, Y., and Qian, P.-Y. (2009). Conservative Fragments in Bacterial 16S rRNA Genes and Primer Design for 16S Ribosomal DNA Amplicons in Metagenomic Studies. PLoS One 4, e7401. doi:10.1371/journal.pone.0007401

Wasmund, K., Cooper, M., Schreiber, L., Lloyd, K. G., Baker, B. J., Petersen, D. G., et al. (2016). Single-Cell Genome and Group-specific dsrAB Sequencing Implicate Marine Members of the Class Dehalococcoidia (Phylum Chloroflexi ) in Sulfur Cycling. mBio 7, e00266. doi:10.1128/ mBio.00266-16

Werne, J. P., Lyons, T. W., Hollander, D. J., Formolo, M. J., and Sinninghe Damsté, J. S. (2003). Reduced Sulfur in Euxinic Sediments of the Cariaco Basin: Sulfur Isotope Constraints on Organic Sulfur Formation. Chem. Geology. 195, 159-179. doi:10.1016/S0009-2541(02)00393-5

Wirth, S. B., Gilli, A., Niemann, H., Dahl, T. W., Ravasi, D., Sax, N., et al. (2013). Combining Sedimentological, Trace Metal (Mn, Mo) and
Molecular Evidence for Reconstructing Past Water-Column Redox Conditions: The Example of Meromictic Lake Cadagno (Swiss Alps). Geochimica et Cosmochimica Acta 120, 220-238. doi:10.1016/ j.gca.2013.06.017

Wurzbacher, C., Fuchs, A., Attermeyer, K., Frindte, K., Grossart, H.-P., Hupfer, M., et al. (2017). Shifts Among Eukaryota, Bacteria, and Archaea Define the Vertical Organization of a lake Sediment. Microbiome 5, 41. doi:10.1186/s40168-017-0255-9

Youssef, N. H., Rinke, C., Stepanauskas, R., Farag, I., Woyke, T., and Elshahed, M. S. (2015). Insights into the Metabolism, Lifestyle and Putative Evolutionary History of the Novel Archaeal Phylum 'Diapherotrites'. ISME J. 9, 447-460. doi:10.1038/ismej.2014.141

Yu, Y., Lee, C., Kim, J., and Hwang, S. (2005). Group-specific Primer and Probe Sets to Detect Methanogenic Communities Using Quantitative Real-Time Polymerase Chain Reaction. Biotechnol. Bioeng. 89, 670-679. doi:10.1002/bit.20347

Zhou, Z., Pan, J., Wang, F., Gu, J.-D., and Li, M. (2018). Bathyarchaeota: Globally Distributed Metabolic Generalists in Anoxic Environments. FEMS Microbiol. Rev. 42, 639-655. doi:10.1093/femsre/fuy023

Conflict of Interest: The authors declare that the research was conducted in the absence of any commercial or financial relationships that could be construed as a potential conflict of interest.

The handling Editor declared a past co-authorship with one of the authors SB, MAL.

Publisher's Note: All claims expressed in this article are solely those of the authors and do not necessarily represent those of their affiliated organizations, or those of the publisher, the editors and the reviewers. Any product that may be evaluated in this article, or claim that may be made by its manufacturer, is not guaranteed or endorsed by the publisher.

Copyright (c) 2022 Berg, Lepine, Laymand, Han, Vogel, Morlock, Gajendra, Gilli, Bernasconi, Schubert, Su and Lever. This is an open-access article distributed under the terms of the Creative Commons Attribution License (CC BY). The use, distribution or reproduction in other forums is permitted, provided the original author(s) and the copyright owner(s) are credited and that the original publication in this journal is cited, in accordance with accepted academic practice. No use, distribution or reproduction is permitted which does not comply with these terms. 